University of Nebraska - Lincoln

DigitalCommons@University of Nebraska - Lincoln

University of Nebraska Press -- Sample Books

and Chapters

University of Nebraska Press

Spring 2013

\title{
A Reference Grammar of Kotiria (Wanano)
}

Kristine Stenzel

Follow this and additional works at: https://digitalcommons.unl.edu/unpresssamples

Stenzel, Kristine, "A Reference Grammar of Kotiria (Wanano)" (2013). University of Nebraska Press -Sample Books and Chapters. 197.

https://digitalcommons.unl.edu/unpresssamples/197

This Article is brought to you for free and open access by the University of Nebraska Press at DigitalCommons@University of Nebraska - Lincoln. It has been accepted for inclusion in University of Nebraska Press -- Sample Books and Chapters by an authorized administrator of DigitalCommons@University of Nebraska - Lincoln. 
A Reference Grammar of Kotiria (Wanano) 
STUDIES IN

THE NATIVE LANGUAGES

OF THE AMERICAS

\section{Editors}

Douglas R. Parks

Raymond J. DeMallie

Recipient of the Mary R. Haas Award

Presented by

The Society for the Study of the Indigenous Languages of the Americas 


\section{A REFERENCE GRAMMAR OF KOTIRIA (WANANO)}

\section{Kristine Stenzel}

University of Nebraska Press

Lincoln and London

In cooperation with the American Indian Studies Research Institute, Indiana University, Bloomington 
(C) 2013 by the Board of Regents of the University of Nebraska

All rights reserved

Manufactured in the United States of America

(@)

This book is published as part of the Recovering Languages and Literacies of the Americas initiative. Recovering Languages and Literacies is generously supported by the Andrew W. Mellon Foundation.

Library of Congress Control Number: 2013937811 
For my husband Jorge and my son Julian 
Buy the Book 


\section{Contents}

List of tables $\quad$ xiii

List of figures and maps $\quad \mathrm{xV}$

Preface xvi

Acknowledgments xvii

Abbreviations used in glosses $\quad$ xix

Abbreviations for example sources xxi

Format of examples and texts xxii

1 The Kotiria and their language 1

1.1 Linguistic diversity in Brazilian Amazonia 1

1.2 The Tukanoan language family 3

1.2.1 Research on Tukanoan languages 6

1.2.2 Research on the Kotiria language 8

1.3 The Kotiria: demographics and geographic location 8

1.4 A brief history of contact 13

1.5 Linguistic exogamy, multilingualism, and the Vaupés
social system

1.6 The specter of language loss and the development $\begin{array}{lr}\text { of language maintenance programs } & 18\end{array}$

2 Phonology 22

2.1 Phonemic inventory 22

2.2 Consonants 23

2.2.1 Plosives: voiced, voiceless unaspirated, voiceless aspirated 24

2.2.2 The relation of $[\mathrm{d}]$ and $[\mathrm{r}] \quad 30$

2.2.3 The affricate $/ \mathrm{t} / / 2$

2.2.4 Allophones of oral consonants 34

$\begin{array}{lll}2.3 & \text { Vowels and vowel harmony } & 36\end{array}$

2.4 The syllable 38

2.4.1 Shapes, constraints, and association rules 38

2.4.2 Moras in prosodic structure 39

2.5 Suprasegmental nasalization $\quad 42$

2.5.1 Nasal allophones and derivations of [ + nasal] morphemes 43

2.5.2 Spreading processes $\quad 45$

2.6 Suprasegmental tone 48

2.6.1 Tone or pitch accent? 48

2.6.2 Derivations and spreading processes 50

2.6.3 Monomoraic roots and tonal melodies 55 
2.7 Suprasegmental glottalization $\quad 59$

2.7.1 Segment or suprasegment? $\quad 60$

2.7.2 Association and derivations 65

$\begin{array}{ll}\text { 2.7.3 Glottalization and preaspiration } & 67\end{array}$

2.8 Cooccurrence of suprasegmentals 69

2.9 Other commonly occurring phonological processes 69

2.9.1 Fusion of like vowels $\quad 69$

2.9.2 Vowel devoicing 71

2.10 The Kotiria practical orthography 72

3 Words 76

3.1 Basic morphological processes 76

3.2 Roots: noun, verb, and particle $\quad 78$

3.3 Verbal words 81

3.3.1 Finite, simple nonfinite, and nominalized nonfinite verbs $\quad 81$

3.3.2 Derived verbs 83

3.4 Nominal words 86

3.4.1 Simple nouns $\quad 86$

3.4.2 Derived nouns 86

3.5 Words expressing adjectival and adverbial notions 87

3.6 Properties of roots, suffixes, and clitics 89

3.7 Phonological and grammatical words 93

3.8 Some considerations on the orthographic word 96

4 Noun classes and noun formation 98

4.1 Noun classes in Eastern Tukanoan languages 98

$\begin{array}{ll}4.2 \text { Animates } & 101\end{array}$

4.2.1 Nouns with human referents: gender and number $\quad 102$

4.2.2 Nonhuman individual animates 107

4.2.3 Inherently collective animates 112

4.2.4 Linguistic coding and the hierarchy of animates 113

4.3 Inanimates 113

4.3.1 Mass nouns 114

$\begin{array}{ll}\text { 4.3.2 Countable nouns: unsuffixed nouns and body part } & \\ \text { nouns with }+ \text { ro } & 116\end{array}$

$\begin{array}{ll}\text { 4.3.3 Inanimates with classifiers } & 119\end{array}$

4.4 General properties of Kotiria noun classification 128

$\begin{array}{ll}4.5 & \text { Derived nouns } \\ & 130\end{array}$

4.5.1 Nominals derived from verbal roots $\quad 130$

4.5.2 Nominals derived from particles 136

4.6 The negative nominal $\sim$ de 140

4.7 Pronouns 142

4.7.1 Deictic forms: first and second person $\quad 142$

4.7.2 Anaphoric forms: third person 143

4.7.3 Anaphoric forms for inanimates 145

4.8 Noun compounds 150 
5 Nominal morphology 152

5.1 Additional morphemes coding lexical information 152

5.1.1 Evaluatives: - $k a$ 'diminutive', $-w \mathcal{w H} r \boldsymbol{H}$ 'augmentative' 153

5.1.2 Other qualifying morphemes: $-k h u$ 'additive', -dita 'solitary', and (-)waro 'emphatic'

156

5.2 Morphemes coding grammatical information 158

$\begin{array}{ll}5.2 .1 & 159\end{array}$

$\begin{array}{ll}5.2 .2 \text { Object }+ \text { re } & 161\end{array}$

5.2.3 Comitative-instrumental $=\sim$ be're 163

5.3 Morphemes coding discourse-level information 164

5.3.1 Referential $=t a \quad 164$

5.3.2 Contrastive subject -se'e 165

$\begin{array}{lll}\text { 5.3.3 Emphatic } \sim h i ' d a & 167\end{array}$

5.3.4 Restrictions and interesting combinations 167

$\begin{array}{lll}5.4 & \text { Review of morphophonological processes } & 169\end{array}$

5.4.1 Nasalization, tone specification, and spreading 169

$\begin{array}{ll}\text { 5.4.2 Status of morphemes } & 171\end{array}$

6 Noun phrases 173

$\begin{array}{lll}\text { 6.1 Constituent order in noun phrases } & 173\end{array}$

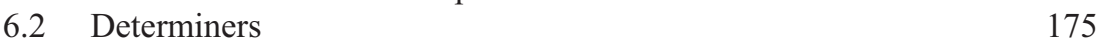

$\begin{array}{lll}6.3 & \text { Quantifiers } & 177\end{array}$

$\begin{array}{ll}\text { 6.3.1 Numbers } & 177\end{array}$

$\begin{array}{ll}\text { 6.3.2 Other quantifiers } & 183\end{array}$

$\begin{array}{lll}6.4 & \text { Possession } & 185\end{array}$

6.4.1 Pronominal possession 186

$\begin{array}{ll}\text { 6.4.2 Possession by a noun or NP } & 187\end{array}$

$\begin{array}{ll}\text { 6.4.3 Locative possession: } \sim \text { baka } & 188\end{array}$

$\begin{array}{ll}\text { 6.4.4 The possessive root ya } & 189\end{array}$

$\begin{array}{lll}6.5 & \text { Interrogatives } & 191\end{array}$

$\begin{array}{lll}\text { 6.5.1 Interrogative nominals } & 191\end{array}$

6.5.2 Interrogative modifiers 193

$\begin{array}{lll}\text { 6.6 Descriptive (adjectival) nominalizations } & 194\end{array}$

$\begin{array}{ll}6.7 & 195\end{array}$

7 Verbal semantics and serialization processes 198

$\begin{array}{lll}7.1 & \text { Stative verbs } & 198\end{array}$

7.1.1 Copula: $h i \quad 199$

7.1.2 Nonexistence: badia 202

$\begin{array}{ll}\text { 7.1.3 Stative possession: } k \text { hta } & 203\end{array}$

$\begin{array}{lll}7.1 .4 & \text { Position } & 204\end{array}$

$\begin{array}{ll}\text { 7.1.5 Adjectival statives } & 206\end{array}$

$\begin{array}{ll}7.2 & \text { Activity verbs } \\ 7.3 & 206\end{array}$

$\begin{array}{lll}7.3 & \text { Motion verbs } & 209\end{array}$

7.3.1 Basic motion verbs: wa' 'go' and ta 'come' 209 
$\begin{array}{lll}\text { 7.3.2 Directional verbs } & 213\end{array}$

$\begin{array}{lll}\text { 7.3.3 Relational motion verbs } & 214\end{array}$

$\begin{array}{lll}\text { 7.3.4 Verbs of placement } & 215\end{array}$

7.4 Verbs of sensory perception and mental processes 216

$\begin{array}{ll}7.5 \text { Common verb serialization constructions } & 221\end{array}$

7.5.1 Motion verbs coding direction or manner 223

7.5.2 Aspectual functions of noninitial verbs 229

7.5.3 Other noninitial roots coding aspect 234

7.5.4 Modal functions of noninitial verbs 238

7.5.5 Other types of serialized constructions 241

$\begin{array}{lll}7.6 & \text { Verbs with incorporated nouns } & 242\end{array}$

8 Nonroot stem morphemes in the verb 244

8.1 Overview of the morphology of finite verbs 244

8.2 Negation: -era 246

8.3 Intensification and emphasis: $-y \boldsymbol{t}$ ' $\boldsymbol{t} \boldsymbol{2} \quad 250$

$\begin{array}{lll}8.4 \text { Modality } & 251\end{array}$

8.4.1 Dubitative: $-b o \quad 252$

8.4.2 Frustrative: $-\sim b a \quad 252$

8.4.3 Favoritive: $-p e \quad 253$

8.4.4 Other modal morphemes 254

8.5 Imperfective and perfective aspect 255

8.5.1 Imperfective aspect: - ati 256

8.5.2 Perfective aspect: $-w a{ }^{\prime} a \quad 258$

8.5.3 The function of the suffix $+a \quad 263$

8.6 Order of verbal morphemes and degree of grammaticalization 264

9 Clause modality 268

$\begin{array}{lll}9.1 & \text { Evidentials: overview and previous analyses } & 269\end{array}$

$\begin{array}{ll}9.2 & \text { A revised analysis of Kotiria evidentials } \\ & 271\end{array}$

9.2.1 Nonfirsthand evidence: hearsay 273

$\begin{array}{ll}\text { 9.2.2 Visual external firsthand evidence } & 274\end{array}$

9.2.3 Nonvisual external firsthand evidence 282

9.2.4 External firsthand evidence: inference 284

9.2.5 Internal firsthand evidence: assertion 285

9.2.6 Hierarchization of evidential categories and the notion
of deixis

9.2.7 Kotiria evidentials and epistemic values 295

9.2.8 Further remarks on the evidential categories 297

$\begin{array}{lll}9.3 & \text { Irrealis } & 298\end{array}$

9.3.1 Prediction and intention $\quad 299$

$\begin{array}{ll}\text { 9.3.2 Negative irrealis } & 301\end{array}$

$\begin{array}{lll}9.4 & \text { Interrogatives } & 303\end{array}$

9.4.1 Aspectual distinctions in questions 304

9.4.2 Questions involving supposition or speculation 305

$\begin{array}{lll}9.5 & \text { Directive modality } & 307\end{array}$ 
9.5.1 Imperative: $+g a \quad 307$

9.5.2 Permissive: $-\sim b a \quad 308$

9.5.3 Admonitive - ri and adversative -kurt 309

9.5.4 Exhortatives: $(\sim s a \ldots) \sim\left(h i^{\prime}\right) d a \quad 310$

9.5.5 Reporting requests, demands, and warnings 311

10 Clause structure $\quad 313$

$\begin{array}{lll}10.1 & \text { Subject agreement } & 314\end{array}$

10.1.1 Subject agreement morphology on realis finite verbs 315

10.1.2 Subject agreement morphology in other constructions 316

10.1.3 Adverbial clauses without subject agreement 319

$\begin{array}{lll}10.2 & \text { Intransitives } & 321\end{array}$

$\begin{array}{lll}10.3 & \text { Transitives } & 321\end{array}$

10.3.1 Objects with and without +re 323

10.3.2 More on the semantics of +re 326

$\begin{array}{lll}10.4 & \text { Ditransitives } & 336\end{array}$

$\begin{array}{lll}10.5 & \text { Verbs with locative arguments } & 337\end{array}$

10.5.1 Stative verbs with locative arguments 337

$\begin{array}{ll}\text { 10.5.2 Motion verbs with locative arguments } & 340\end{array}$

10.5.3 Another verb with object and oblique arguments 343

$\begin{array}{lll}10.6 \text { Valency-changing roots } & 344\end{array}$

$\begin{array}{ll}10.7 \text { Adjuncts } & 345\end{array}$

10.7.1 Locative 346

10.7.2 Temporal expressions and adjuncts 348

10.7.3 Comitative 353

10.7.4 Instrumental 354

10.7.5 The status of $=\sim$ be're 355

11 Complex sentences $\quad 357$

11.1 Order of constituents in clauses 357

$\begin{array}{lll}11.2 & \text { Preverbal modification } & 358\end{array}$

11.2.1 Adverbials: quality and evaluation 358

11.2.2 Adverbials: manner $\quad 359$

11.2.3 Adverbials: hi'da 'emphatic' $\quad 361$

11.2.4 Adverbials: similarity, comparison, and contrast 363

11.2.5 Adverbials: interrogative 366

11.3 Verbs with clausal complements 368

11.3.1 Modal with $\sim$ kha'ba 368

11.3.2 Progressive with $\sim d i \quad 369$

11.3.3 Purposive with wa' $a$ and ta $\quad 371$

$\begin{array}{ll}11.4 \text { Quoted speech constructions } & 371\end{array}$

11.5 Perfective and causative constructions with yoa 373

$\begin{array}{lll}11.6 & \text { Other clauses with sequences of verbs } & 376\end{array}$

11.7 A summary comparison of multiple-verb constructions 379 
Appendix 1: Texts

380

Oral narratives

380

Written texts from Let's Study in Kotiria

450

Appendix 2: Vocabulary

457

References

487

Index

499 


\section{List of tables}

Table 1.1 Sorensen's classification of Eastern Tukanoan 5

Table 1.2 Classification of the Tukanoan family according

to Waltz and Wheeler (1972) and Barnes (1999) 5

Table 1.3 Classification of Tukanoan according to Ramirez 5

Table 2.1 Kotiria consonant phonemes 22

Table 2.2 Kotiria vowel phonemes 23

Table 2.3 Cognates of Kotiria words with initial unaspirated

Table 2.4 Disyllabic roots with word-initial voiceless plosives 29

Table 2.5 $C V$ roots with word-initial voiceless plosives 29

Table 2.6 Kotiria aspiration from deletion of vowel before $/ \mathrm{h} / \quad 30$

$\begin{array}{ll}\text { Table 2.7 } & \begin{array}{l}\text { Correspondences between Kotiria [t] } \\ \text { Tukanoan }[\mathrm{k}]\end{array}\end{array}$

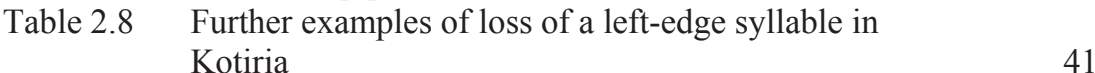

Table 2.9 Kotiria $C V$ roots with $C V V$ cognates in Wa'ikhana 42

Table 2.10 Some minimal pairs for nasalization 43

Table 2.11 Kotiria [Ønasal] morphemes 46

Table 2.12 Monomoraic roots with initial L tone 59

Table 2.13 Minimal pairs for glottalization in $C V C V$ roots 59

Table 2.14 Minimal pairs for glottalization in $C V V$ roots $\quad 59$

Table 2.15 Cognates of Kotiria words with glottal stop coda 61

Table 2.16 Words with LH or LHL melody and no glottal stop 64

Table 2.17 Contrast of glottal stop and preaspiration 67

Table 2.18 Contrasts of suprasegmentals within roots 68

$\begin{array}{lll}\text { Table 2.19 Characteristics of suprasegmentals } & 70\end{array}$

Table 3.1 Distribution of morphemes per word in two Kotiria texts 78

$\begin{array}{lll}\text { Table } 3.2 & \text { Root shapes } & 79\end{array}$

Table 3.3 Properties of morphemes 90

Table 4.1 Animate nouns 102

Table 4.2 Inanimates 114

$\begin{array}{lll}\text { Table } 4.3 & \text { Personal pronouns } & 142\end{array}$

Table 5.1 Phonological specification of nominal morphemes 172

$\begin{array}{lll}\text { Table } 6.1 & \text { Possessive proclitics } & 186\end{array}$ 
$\begin{array}{lll}\text { Table } 9.1 & \text { Clause modality } & 269\end{array}$

Table 9.2 Kotiria evidentials according to Waltz and Waltz 271

$\begin{array}{ll}\text { Table 9.3 } & \begin{array}{l}\text { Subject agreement suffixes for irrealis and nominalized } \\ \text { verbs }\end{array}\end{array}$

Table 10.1 Arguments and adjuncts 314

Table 10.2 Subject agreement suffixes for irrealis and nominalized verbs

Table 10.3 Word order and argument coding in Eastern Tukanoan languages

Table 10.4 Marking of adjuncts

Table 11.1. Properties of multiple-verb constructions 


\section{List of figures and maps}

\section{Figures}

Figure 3.1 Relations between phonological word and grammatical word in the surface form of verbal words

Figure 3.2 Relations between phonological word and grammatical word in the surface form of nominal words

Figure 3.3 Relations between phonological word and grammatical word in the surface form of particle-root nominal words $\quad 96$

Figure 4.1 Major features of Kotiria noun classes 101

Figure 4.2 Hierarchy of animates 113

$\begin{array}{lll}\text { Figure 4.3 The noun classification continuum } & 129\end{array}$

Figure 5.1 Nominal morphology 152

Figure 6.1 Morphology of number modifying constructions 182

Figure 6.2 Order of modifiers within the NP 196

Figure 8.1 Morphology of finite verbs 245

Figure 8.2 Relatively lexical vs. relatively grammatical properties of noninitial morphemes in the verb 265

Figure 9.1 Revised analysis of Kotiria evidentials 272

Figure 9.2 Alignment and mismatches of aspect in evidentials and events or states

Figure 9.3 Interrogative clause modality compared with statement clause modality 303

Figure 11.1 A sample form from a Kotiria linguistic census 359

\section{Maps}

Map 1.1 Location of ethnic-linguistic groups in the Vaupés region 


\section{Preface}

This grammar is the result of ten years of ongoing study of the Kotiria language and practical work on language issues with the Kotiria people. It is a slightly expanded and substantially reorganized version of my dissertation, completed in 2004 at the University of Colorado, and is based on a corpus of primary data that includes an extensive lexical database and dozens of recorded narratives (seven of which are given with full interlinear analysis in appendix 1), elicited words and sentences, texts written by the Kotiria themselves (five of these are included in appendix 1), and observations during numerous field trips to Kotiria communities from 2000 on. The analysis both builds on previous research and suggests new hypotheses and avenues of investigation.

The portrait of the language offered here is not exhaustive; although I have tried to present an overview that is as comprehensive as possible, there are certainly many issues yet to be investigated. It is nevertheless my hope that this grammar will be a useful tool not only for researchers of Tukanoan and other Amazonian languages, but also for typologists in general, as well as theoretical linguists who look to descriptions of languages as an essential source of primary language data. With this in mind, I have adopted a basic functional-typological framework, and have tried to offer ample exemplification and argumentation for each hypothesis or affirmation presented. 


\section{Acknowledgments}

This research would not have been possible without generous aid from a number of organizations and individuals in the Un ited States and in Brazil whom I would like to gratefully acknowledge. First, I would like to reiterate my thanks to the Univ ersity of Colorado department of linguistics and to Drs. Jule Go mez de Garcia, David Rood, Zygmunt Frajzyngier, and Barbara Fox for their guidance and support during the early years of my work on Kotiria. Thanks are also due to a number of other scholars whose gene rous exchange of ideas and encouragement over the years have greatly contributed to this work, in particular Elsa Gomez-Imbert, Patience Epps, Bruna Franchetto, Janet Chernela Henri Ramirez, Alexandra Aikhenvald, Denny Moore, and Nathan and Carolyn Waltz. Additionally, heartfelt appreciation goes to Paul Kroeber for his excellent editorial guidance and to Renata Alves of the Instituto Socioambiental for her design of the $\mathrm{m}$ ap. Moreover, I am sincerely grateful to the Instituto So cioambiental, to the staff of their Rio Negro Program in São Gabriel da Cachoeira, and to my colleagues Marta Azevedo and Lúcia Alberta Andrade for their assist ance and comradeship in the field.

I do not even know how to begin to thank the Kotiria people, who have not only shared their language with me, but have also welcomed me into their co mmunities and taken care of me with great skill, sincere affection, and much good humor. I am particularly indebted to my primary consultants: Mateus Cabral, Agostinho Ferraz, Ricardo Cabral, Emília Cabral, and Do mingos Cabral; professors and students of the Kotiria school: José Galves Trindade, Elizabete Teixeira, Fausto Ferraz, Mariano Gama Alvarez, Silvestre Galvão Trindade, and Ediberto Almeida Teixeira, am ong others; the residents of the Kotiria communities of Carurú Cachoeira, Arara Cachoeira, Matapí, Jutica, Ilha de Inambú, and Jacaré, as well as my Kotiria friends in IauaretêEngênio Trindade and his wife El sa, Mario Figueiredo and his wife Leopoldina-for their goodwill and hospitality.

Finally, over the y ears, my research with the Kotiria has rec eived essential financial, institutional, and logistic support from a number of different sources whom I sincerely thank: the University of Colorado Graduate School, the Endangered Languages Fund, the Wenner-Gren Foundation, the National Scien ce Foundation and the National Endowment for the Humanities (dissertation grant 0211206 and DEL fellowship 52150-05), the Brazilian National Counsel for Scientific 
and Technological Development, the Hans Rausing En dangered Languages Project (School of Oriental and African Studies, University of London, grant MDP-0155), the Ins tituto Socioambiental (in São Paulo and S ão Gabriel da Cachoeira), the Museu Paraense E mílio Goeldi, and the Graduate Program in Social Anthropolo gy and the Department of Linguistics and Philol ogy of the Federal University of Rio de Janeiro. 


\section{Abbreviations used in glosses}

Section numbers (with $\S$ ) indicate where the principal discussions of grammatical categories can be found (these are not necessarily the only places where a given category is discussed).

\begin{tabular}{|c|c|}
\hline $1 / 2 / 3$ & $\begin{array}{l}\text { first/second/third person (pronouns, } \S 4.7, \S 6.4 .1 \text {; verb } \\
\text { inflection, } \S 9.2, \S 9.3 .1, \S 10.1 \text { ) }\end{array}$ \\
\hline ADD & additive $(\$ 5.1 .2)$ \\
\hline ADMON & admonitive $(\S 9.5 .3)$ \\
\hline ADVERS & adversative ( $\$ 9.5 .3)$ \\
\hline AFFEC & affected $(\S 8.5 .3)$ \\
\hline ALT & alternate $(\S 4.5 .2, \S 6.2)$ \\
\hline ANPH & anaphoric $(\S \S 4.7 .2-4.7 .3, \S 6.2)$ \\
\hline ASSERT & assertion $(\$ 9.2 .5)$ \\
\hline AUG & augmentative $(\S 5.1 .1)$ \\
\hline [B] & word borrowed from Portuguese \\
\hline BEN & benefactive $(\S 10.6)$ \\
\hline CLS & classifier $(\$ 4.3 .3)$ \\
\hline COLL & collective $(§ 7.5 .3)$ \\
\hline $\mathrm{COM}$ & comitative $(\S 5.2 .3, \S 10.7)$ \\
\hline COMPL & completive $(\$ 7.5 .3)$ \\
\hline COMP & comparative $(\S 11.2 .4)$ \\
\hline CONTR & contrastive subject $(\S 5.3 .2, \S 11.2 .4)$ \\
\hline $\mathrm{COP}$ & copula $(\S 7.1 .1)$ \\
\hline CQUANT & quantifier of count noun $(\S 6.3 .2, \S 6.5 .2)$ \\
\hline $\mathrm{DEF}$ & definite $(\$ 4.7 .3)$ \\
\hline DEIC & deictic $(\S 4.5 .2, \S 6.2)$ \\
\hline DEM & demonstrative $(\S 4.5 .2, \S 6.2)$ \\
\hline DESID & desiderative $(\S 7.4, \S 7.5 .4)$ \\
\hline DIFF & diffuse $(\$ 9.2 .1)$ \\
\hline DIM & diminutive $(\$ 5.1 .1)$ \\
\hline DIST & distal (demonstrative or deictic, $\S 4.5 .2$; aspect, $§ 7.5 .2$ ) \\
\hline DUB & dubitative $(\S 8.4 .1)$ \\
\hline EMPATH & empathetic $(\S 8.4 .4)$ \\
\hline EMPH & emphatic $(\S 5.1 .2, \S 5.3 .3, \S 11.2 .3)$ \\
\hline EXC & exclusive $(\$ 4.7, \S 6.4 .1)$ \\
\hline EXRT & exhortative $(\$ 9.5 .4)$ \\
\hline FAV & favoritive $(\$ 8.4 .1)$ \\
\hline FEM & feminine $(\S 4.2 .1, \S 9.3, \S 10.1 .2)$ \\
\hline FRUS & frustrative $(\S 8.4 .2)$ \\
\hline HSAY & hearsay $(\S 9.2)$ \\
\hline IMPER & imperative $(\$ 9.5 .1)$ \\
\hline
\end{tabular}




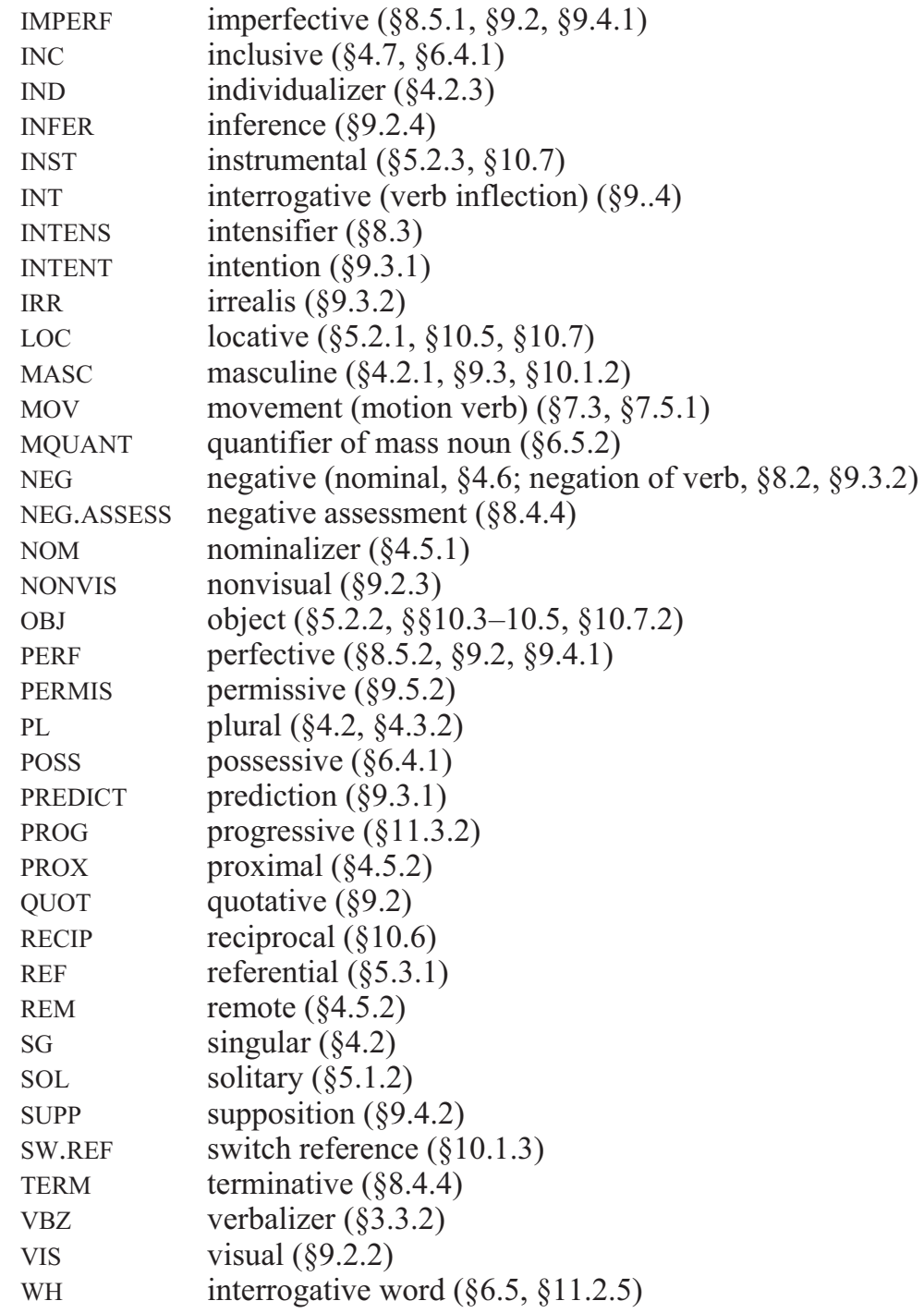




\section{Abbreviations for example sources}

Examples from the texts in appendix 1 are indicat ed by " $A$ " followed by the text number and sentence number; thus "[A7.14]" indicates that the example comes from sentence 14 of text 7.

Examples from other texts not included in appendix 1 are identified by the abbreviated codes in the list below. (Sentence nu mbering is not given; some of these texts are not y et publicly available, and numbering could change before they appear.)

1. Oral narratives and conversations:

Manioc "Foods Made From Manioc": an explanation of how manioc, a staple of the Kotiria diet, is processed and of the different foods made from it

Ancestors "How Our Ancestors Got Women": a narrative recounting an unsuccessful "bride-napping" trip to a nearby village undertaken by a group of young men

Baskets "A Conversation about Baskets": a conversation in which three women examine and comment on some baskets and other woven items

2. Written texts from the book Let's Study in Kotiria: Kotiria Animal Stories (see appendix 1 for a general description of this book and how it was written):

$\begin{array}{ll}\text { LSK: Agoutis } & \text { LSK: Frogs } \\ \text { LSK: Anteaters } & \text { LSK: Limes } \\ \text { LSK: Armadillos } & \text { LSK: Parrots } \\ \text { LSK: Bananas } & \text { LSK: Snakes } \\ \text { LSK: Buriti } & \text { LSK: Squirrels } \\ \text { LSK: Cows } & \text { LSK: Tails } \\ \text { LSK: Deer } & \text { LSK: Toucans } \\ \text { LSK: Dogs } & \text { LSK: Turtles } \\ \text { LSK: Firewood } & \text { LSK: Wasps } \\ \text { LSK: Fish } & \end{array}$




\section{Format of examples and texts}

Most examples follow the four-line format in (1). T he first line gives the utterance using the orthography currently employed by the Kotiria with whom I have been working. (See $\S 1.6$ for information on the Kotiria school and the current state of discussions on orthogr aphy development, and $\$ 2.10$ for an explanation of the practical orthography.) In the second line, words are divided into morphem es and are written in an orthography that is closer to the basic phonol ogical form of morphemes and that also includes tone marking (with acute accent marking high tone). The third line gives morpheme-by-morpheme glosses of the Kotiria forms. The fourth line provides a free translation in English. (Portuguese words occasi onally appear when no exact English equivalent for a Kotiria term is available.)

(1) $y$ 't Mo mahkariropu hiha

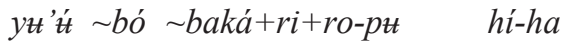

1SG Mõ village+NOM+SG-LOC COP-VIS.IMPERF.1

'I am from Mõ (the village of Carurú Cachoeira).'

The texts in appendix 1 follow essentially the same format. 


\section{The Kotiria and their language}

This chapter introduces the Kotiria ${ }^{1}$ people, their language, and the sociolinguistic context in which it is spoken. An overview of linguistic diversity in Amazonia, of Kotiria's place within the Tukanoan language family, ${ }^{2}$ and of the history of research is presented in $\S \S 1.1-1.2$. Kotiria demography, location, and contact history are sketched in $\S \S 1.3-1.4$. Section 1.5 outlines important features of the Vaupés social system, focusing on linguistic exogamy, multilingualism, and language contact, and $\$ 1.6$ surveys current language maintenance and documentation efforts.

\subsection{Linguistic diversity in Brazilian Amazonia}

The Amazonian basin, covering parts of Peru, Bolivia, Ecuador, Venezuela, Colombia, and Brazil, is one of the world's most linguistically diverse regions (for details, see the articles in UNESCO 2006). Currently, it is within the Brazilian portion of the basin, known officially as "Amazônia Legal"3 (henceforth "Brazilian Amazonia"), that

${ }^{1}$ During the eight years I have worked with this language community, there has been a change in their attitude towards the name "Wanano," by which the group is generally known to the outside world. There are, in fact, several versions of this name-Wanano, Guanano, and Uanano - that appear alternately in the literature; however, it is name that has no meaning in their own language, nor does anyone seem to know its origin or meaning in any other language. It is a name given by unknown outsiders and its use has been called into question by village leaders and the directors, teachers, and students of the indigenous school. In 2006, the group publicly adopted the policy of using exclusively their own traditional name Kotiria 'water people' to refer to themselves and to their language and have requested that the outsiders working with them do the same. Indeed, other groups throughout the region have made similar requests, among them the Wa'ikhana (also known in the region as Piratapuyo), with whom I also work. Such decisions alongside other expressions of pride and selfdetermination reflect the increasing empowerment of local groups and strengthening of long-repressed self-esteem.

2 Both the terms "Tukano" and "Tukanoan" are used in the literature to refer to the language family. For clarity in this work, I use "Tukano" to refer to the language and "Tukanoan" to refer to the language family as a whole.

3 "Legal Amazonia" includes all the states of Brazil's northern region: Acre, Amazonas, Amapá, Pará, Rondônia, Roraima, and Tocantins, as well as the centralwest state of Mato Grosso, and the portion of the northeastern state of Maranhão lying west of the forty-fourth meridian. This macroregion shares borders with Bolivia, Peru, Colombia, Venezuela, Guyana, Surinam, and French Guiana, and covers 
we find both the highest concentration of indigenous people and the greatest density of languages within this vast rainforest: over 140 languages, belonging to some forty different families (Moore 2006). ${ }^{4}$ There are moreover, two creole languages, seven languages classified as isolates, and an estimated forty-five to sixty indigenous groups with whom there is still little or no contact, and about whose languages virtually nothing is known.

In the 2010 national census, ${ }^{5}$ the total population of Brazil figures at slightly under $191,000,000$, and the indigenous population is listed as approximately 818,000 , an increase of 11.4 percent over the decade. ${ }^{6}$ Nonetheless, although the indigenous population of Brazil has grown steadily over the past twenty-five years, it still represents only 4 percent of the total population.

Thus, Brazil's total indigenous population is proportionately quite small, and the sizes of individual indigenous groups vary greatlyMoore and Gabas (2006) estimate that only 15 percent of the groups have more than a thousand speakers. Ten percent have between 501 and 1,000, 18 percent have 251 to 500,25 percent have 101 to 250,8 percent have 51 to 100 , and 24 percent have 50 or fewer. The average population size of indigenous groups in Brazil is less than two hundred speakers (Leite and Franchetto 2006). These statistics point to a serious state of endangerment for virtually all of the indigenous languages spoken in Brazilian Amazonia; indeed, it is predicted that, even with current growing efforts to protect indigenous languages and oral

approximately 5,217,423 $\mathrm{km}^{2}$, corresponding to approximately 61 percent of Brazilian territory. Together, the states of Amazonas and Pará represent more than 55 percent of this total.

${ }^{4}$ Both numbers of groups and numbers of languages vary in different sources. The Instituto Socioambiental (Socioenvironmental Institute, ISA), the foremost source of information on Brazil's indigenous population, lists a total of 225 ethnic indigenous groups within Brazilian territory (Ricardo and Ricardo 2006), while the Conselho Indigenista Missionário (Indian Missionary Council) lists 241 groups on their website (http://www.cimi.org.br/). As for the total number of indigenous languages, the generally cited figure for all of Brazil is 170 to 180 (Rodrigues 2005). The slightly more conservative figure cited here corresponds to the more rigorous linguistic, rather than ethnic or political, criteria used as a basis for classification by Moore (2006).

${ }^{5}$ This information is from the website of the Instituto Brasileiro de Geografia e Estatística (Brazilian Institute of Geography and Statistics); see http://www.ibge.gov .br/censo2010/resultados_do_censo2010.php.

${ }^{6}$ Sources such as Franchetto (2005) and the ISA website, however, indicate the indigenous population to be in the $380,000-450,000$ range. These differences are due to use of different classificatory criteria, the National Census figure being solely based on a question on the census form that calls for self-classification as to "Color/Race," the choices being "White," "Black," "Yellow," "Mixed [Pardo]," or "Indian," while the sources showing lower estimates base their count on mixed criteria including, among other factors, place of residence and use of indigenous languages. 
traditions, ${ }^{7}$ more than half of these languages will be silenced before the end of this century.

\subsection{The Tukanoan language family}

The languages of the Tukanoan family are spoken in northwestern Amazonia, including areas of Brazil, Colombia, Ecuador, and Peru. The Western branch consists of four language groups with a total population of around four thousand: the Colombian Koreguaje are the largest group (totaling 1,745); the Secoya and Siona, located in Colombia and Ecuador, have a combined population of approximately two thousand (the Colombian Siona being the larger group, numbering 1,675); and the Orejón in Peru number some four hundred. ${ }^{8}$ Speakers of Western Tukanoan languages have little contact with speakers of Eastern Tukanoan languages, spoken in the Brazilian state of Amazonas and in the Colombian department of Vaupés. The Eastern branch is comprised of sixteen languages: ${ }^{9}$ Bará (also known as Waimajã), Barasana, Desano, Karapana, Kotiria (also known as Wanano), Kubeo, Makuna, Pisamira, Siriano, Taiwano (also known as Eduuria), Tanimuka (also known as Retuarã), Tatuyo, Tukano, Tuyuka, Wa'ikhana (also known as Piratapuyo), and Yuruti. ${ }^{10}$ Of these, only Desano, Koti-

\footnotetext{
${ }^{7}$ For a more thorough overview of current policies and initiatives, see Stenzel (2006).

${ }^{8}$ Population statistics for Colombia are from the 2005 General Census (www.dane .gov.co/censo/). Other resources consulted are Licht and Reinoso (2006), Mondragón (2006), and the Consolidación de la Amazonía website (http://www.coama.org.co/). The Colombian census also gathered information about language use, showing that Koreguaje is spoken by 80 percent of the ethnic population, while only 24 percent of the Siona population use their language.

${ }^{9}$ A review of the literature reveals a great deal of variation of spellings for these language names. We find, for example, Desana/Desano, Tuyuca/Tuyuka, Kubeo/ Cubeo, Waimahã/Waimajã, among others. The forms adopted here reflect current tendencies in the region (e.g., a preference for use of $k$ rather than $c$ ) and requests for self-determined denomination, as mentioned in $\mathrm{n} .1$.

${ }^{10}$ Classifications of Eastern Tukanoan languages vary. Sorensen's (1967) list of thirteen languages did not include Makuna, Pisamira, or Tanimuka/Retuarã. Waltz and Wheeler's (1972) classification did not include Tanimuka/Retuarã, Pisamira, Taiwano/ Eduuria or Yuruti, but did include Papiwa. Malone's (1987) list included neither Taiwano/Eduuria nor Pisamira. The most recent classifications are those of Barnes (1999), which includes Tanimuka/Retuarã, Taiwano/Barasana, and Bará/Waimajã as a single language, Ramirez (1997a), which includes Waimahã as a separate language, but does not include Pisamira or Taiwano, and Gomez-Imbert and Kenstowicz (2000), the source for the sixteen languages listed here. The sixteenth edition of Ethnologue (Gordon and Grimes 2005) lists twenty-five languages in total. For the Eastern branch, they include Waimahã as a dialect of Bará, Pokanga as a dialect of Barasana, and Arapaso as a dialect of Tukano. They also list two extinct Eastern Tukanoan languages:
} 
ria, Tukano, Tuyuka, Kubeo, and Wa'ikhana are spoken by populations divided between the two countries. The remainder are spoken almost exclusively in Colombia. The total population of the Eastern Tukanoan groups, in both Brazil and Colombia, is approximately twenty-six thousand (Federação das Organizações Indígenas do Rio Negro, Instituto Socioambiental 2006:42-48, and the 2005 Colombian census.). There is little reliable information as to actual numbers of speakers among the Eastern Tukanoan groups living in Brazil. However, information on language use gathered during the Colombian census of 2005 shows that among the Eastern Tukanoan populations living in Colombia, the Taiwano language is currently used by only 25 percent of the ethnic population (itself numbering only 166), and that Bará, Pisamira, and Tatuyo are spoken by less than half (42 to 45 percent) of their respective populations, while the remaining languages are used by 60 to 80 percent of their total populations. In Brazil, Tukano is undoubtedly the most widely spoken language, with over six thousand speakers. Moreover, a process of language shift to Tukano affecting the Eastern Tukanoan groups in the Vaupés subregion (most notably the Desano and Wa'ikhana) can currently be observed. This process, spurred by migration out of traditional territories and outside interference, has led to the breakdown of language transmission patterns and cultural practices among these populations (discussed further in Stenzel 2005).

Since scholarship on Tukanoan languages began, several subclassifications of Tukanoan languages have been proposed. Sorensen (1969) made no reference at all to the Western languages, but posited four subgroups of Eastern Tukanoan, as in table 1.1. (Sorensen did not label the subgroups; they are numbered in the table for convenience of reference.)

Barnes (1999), following Waltz and Wheeler (1972), proposes subgrouping for the entire family as in table 1.2. This classification, however, has been questioned by Franchetto and Gomez-Imbert, particularly in regard to the "Central" group (2003:233). They argue that there are no solid linguistic criteria to sustain a "Central" group that is, moreover, composed of the geographically southernmost (Tanimuka/ Retuarã) and northernmost (Kubeo) groups.

Based on a study of cognates (Huber and Reed 1992), Ramirez (1997a:17) establishes seven subgroups that he labels as "languages"; he refers to individual members of subgroups as "dialects" (table 1.3; the numbers correspond to his subgroups).

Yahuna, whose speakers have shifted to Makuna, and Miriti(tapuya), whose speakers have shifted to Tukano. Tanimuka is listed as a Western language. 
TABLE 1.1. SORENSEN'S CLASSIFICATION OF EASTERN TUKANOAN

\begin{tabular}{llll}
\hline 1 & 2 & 3 & 4 \\
Tukano & Piratapuyo & Desano & Kubeo \\
Tuyuka & Wanano & Siriano & \\
Yuruti & & \\
Paneroa (Barasana) & & \\
Eduuria & & \\
Karapana & & \\
Tatuyo & & \\
Barasana & & \\
\hline
\end{tabular}

TABLE 1.2. ClASSIFICATION OF THE TUKANOAN FAMILY ACCORDING TO WALTZ AND WHEELER (1972) AND BARNES (1999)

\begin{tabular}{llllll}
\hline WESTERN & WESTERN & CENTRAL & EASTERN & EASTERN & EASTERN \\
NORTH & SoUth & & NORTH & CENTRAL & SOUTH \\
Orejón & Koreguaje & Kubeo & Piratapuyo & Bará/ & Barasana/ \\
& Secoya & Tanimuka/ & Tukano & Waimahã & Taiwano \\
& Siona & Retuarã & Wanano & Tatuyo & Makuna \\
& & & & Karapana & \\
& & & & Tuyuka & \\
& & & & Desano & \\
& & & & Yuruti & \\
& & & Siriano & \\
\hline
\end{tabular}

TABLE 1.3. ClasSIFICATION OF TUKANOAN ACCORDING TO RAMIREZ

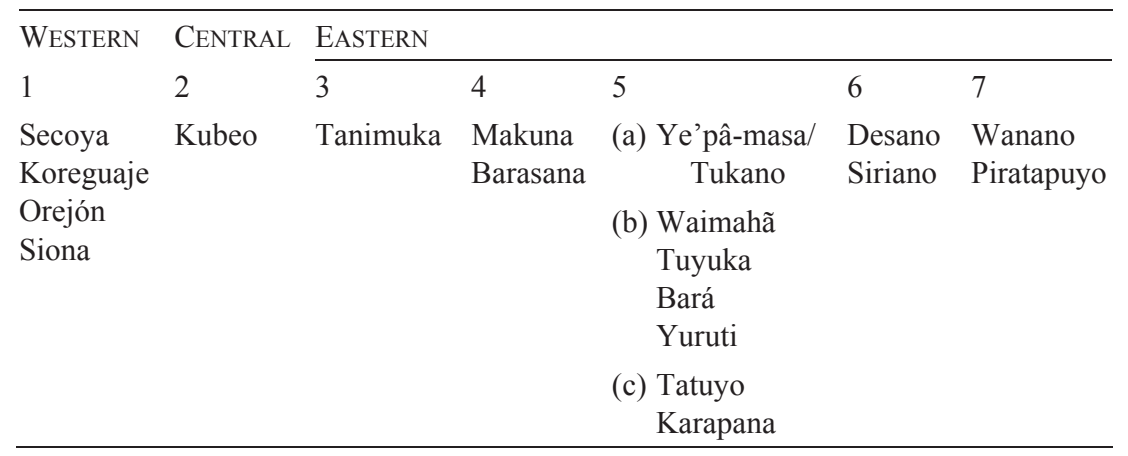


It is clear that more detailed descriptions of individual languages are needed before a definitive classification of the languages in the family can be established. However, the available literature does indicate that certain languages are indeed closely related, among them Kotiria and Wa'ikhana. Waltz (2002), for example, offers an analysis of some of the phonological and morphological similarities and differences between these closely related languages and the ways each has evolved from a reconstructed protolanguage.

\subsubsection{Research on Tukanoan languages}

Research on the languages of the Tukanoan family began to make its way into the linguistics literature in the late 1960s. Among the first analyses to appear were Sorensen's article focusing on the exogamic marriage system of the northwest Amazonian peoples and their resulting multilingualism (Sorensen 1967) and his dissertation on Tukano (Sorensen 1969). During this same period, several collections of phonological sketches of indigenous languages being studied by Summer Institute of Linguistics (SIL) linguists in Colombia were also published; among these were sketches of some of the Eastern Tukanoan languages, including Wanano/Kotiria ${ }^{11}$ (Waltz and Waltz 1967) and Piratapuyo/Wa'ikhana, its closest sister language (Klumpp and Klumpp 1973). Shortly thereafter, pedagogical grammars of Guanano/Kotiria (Waltz 1976) and Tukano (West 1980) were published in Colombia.

Following a tradition of ethnographic observation beginning with Theodor Koch-Grünberg (1995 [originally published in 1909]) in the first decade of the twentieth century and consolidated in mid-century with works such as Goldman's (1963) study of the Kubeo, a number of excellent anthropological publications on Tukanoan groups were produced during the and 1970s and 1980s. Both Reichel-Dolmatoff (1971) and Buchillet (1983) worked with the Desano. There are superb studies of the Barasana (C. Hugh-Jones 1979; S. Hugh-Jones 1979) and the Makuna (Ärhem 1981), and an excellent analysis of linguistic exogamy in the region based on research with the Bará (Jackson 1983). During the same period, Chernela (e.g., 1983, 1989, 1993) published a number of interesting studies on aspects of Kotiria culture. In addition, Bruzzi (1977) offers insights on Vaupés culture from the Salesian missionary perspective and Ribeiro (1995) provides a fascinating overview of production and trade among all the groups. More recently, we find work on the Tuyuka (Cabalzar 2000), as well as studies focusing on the

\footnotetext{
${ }^{11}$ The Waltzes used the Spanish form of the group's name, "Guanano," in their publications up to the 1990 s.
} 
evolution of and changes in Tukanoan culture resulting from migration and interaction with outside cultures (Lasmar 2005; Andrello 2006).

The list of publications related to Tukanoan languages has grown and diversified steadily over the past two decades. There are extensive studies or reference grammars of the Eastern Tukanoan languages Barasana (Gomez-Imbert 1997a; Jones and Jones 1991), Desano (Miller 1999), Kubeo (Morse and Maxwell 1999), and Tukano (Sorensen 1969; Ramirez 1997a, 1997b), and two reconstructions of Proto-Tukanoan (Waltz and Wheeler 1972; Malone 1987). Additionally, there are articles that focus on phonological elements of particular languages (Kaye 1971; Barnes 1996; Gomez-Imbert 2001, 2005; Gomez-Imbert and Kenstowicz 2000; Stenzel 2007a) as well as studies relating to cross-linguistic typological issues such as switch-reference (Longacre 1983), noun classification (Gomez-Imbert 1982, 1996, 2007c; Barnes 1990; Derbyshire and Payne 1990; Aikhenvald 2000), evidential systems (Barnes 1984; Frajzyngier 1985; Willett 1988; Malone 1988; Gomez-Imbert 1997a, 1999a, 2003a, 2007; Aikhenvald and Dixon 1998; de Haan 1999, 2001a; Aikhenvald 2003a, 2004; Stenzel 2008), language contact phenomena (Aikhenvald 2002a; Stenzel and GomezImbert 2009), and most recently, serial verb constructions (Aikhenvald 2006; Gomez-Imbert 2007a; Stenzel 2007b).

There have been several attempts to bring together some of the accumulated findings related to the Tukanoan language family, among them a chapter by Janet Barnes in Dixon and Aikhenvald's overview of Amazonian languages (1999). This chapter presents a very general overview that focuses on some of the common characteristics of languages in the family rather than on the features on which they differ. More detailed information on individual languages in the family can be found in the Instituto Caro y Cuervo's catalogue of linguistic data on the indigenous languages of Colombia (Gonzáles de Pérez and Rodríguez de Montes 2000). This immense publication includes a large section with grammatical sketches and wordlists from thirteen Eastern Tukanoan languages: Tatuyo, Karapana, Bará, Barasana, and Makuna (Gomez-Imbert and Hugh-Jones 2000), Kubeo (Ferguson et al. 2000), Pisamira (Gonzáles de Pérez 2000), Siriano (Criswell and Brandrup 2000), Tukano (Welch and West 2000), Tuyuka (Barnes and Malone 2000), Yuruti (Kinch and Kinch 2000), Wa'ikhana/Piratapuyo (Ardila 2000), and Kotiria/Wanano (Waltz and Waltz 2000). Though these sketches were actually written in the late 1980s and vary in size and detail, their publication in one volume represents an important source of cross-linguistic data on the family. Most recently, we find short overviews of the language family by Barnes (2006) and Gomez-Imbert (2011). 


\subsubsection{Research on the Kotiria language}

The first known grammatical outline of Kotiria was written by the Salesian missionary Antônio Giacone (1967), ${ }^{12}$ and was followed shortly thereafter by a great amount of work on the language by Nathan and Carolyn Waltz. The Waltzes worked with the Kotiria under the auspices of the Summer Institute of Linguistics in Colombia (known there as "Instituto Lingüístico de Verano") for over thirty years (196396). They lived for short periods in the communities of Santa Cruz and Villa Fátima, and then for twenty-six years in Jutica (Ñapima), where they conducted language studies and religious activities such as Bible study, hymn singing, and Bible video nights. They additionally organized courses on farming, animal husbandry, mechanics, guitar, carpentry (in a sawmill they set up), and writing. They moreover proposed an orthography and developed and distributed a number of teaching materials for use in village schools. Their publications include a translation of the New Testament (Waltz, Waltz, and Melo 1982), a pedagogical grammar (Waltz 1976), several papers on aspects of Kotiria phonology (Waltz and Waltz 1967; Waltz 1982), a volume containing a study of kinship terms, a grammatical sketch of the language, and a lengthy interlinearized text (Waltz and Waltz 1997), and the grammatical overview of the language found in the Caro y Cuervo collection (Waltz and Waltz 2000). Nathan Waltz also coauthored the only published reconstruction of Proto-Tukanoan (Waltz and Wheeler 1972). Before his death in 2005, he published an important comparative analysis of Kotiria and Wa'ikhana (Waltz 2002), and completed work on a bilingual (Wanano-Spanish) dictionary, posthumously published in Colombia (Waltz 2007). ${ }^{13}$

\subsection{The Kotiria: demographics and geographic location}

The Kotiria ethnic-linguistic group numbers some 2,000, approximately 65 percent of whom live in Colombia (1,300, according to the 2005 Colombian census) and 35 percent in Brazil (Federação das Organizações Indígenas do Rio Negro and Instituto Socioambiental 2006:43). The majority of the Kotiria population still lives in their traditional territory, covering most of the east-west stretch of the Vaupés River

\footnotetext{
12 Giacone used the name "Uanano" for the language.

${ }^{13}$ I was very pleased to be able to help Carolyn Waltz with the distribution of the dictionary after it was published and to see how excited the Kotiria were to have access to this important resource. As they looked through the dictionary, many of the younger speakers were surprised to find examples of words and expressions that reflect differences between their speech and that of their Colombian relatives, or that have undergone change over time.
} 


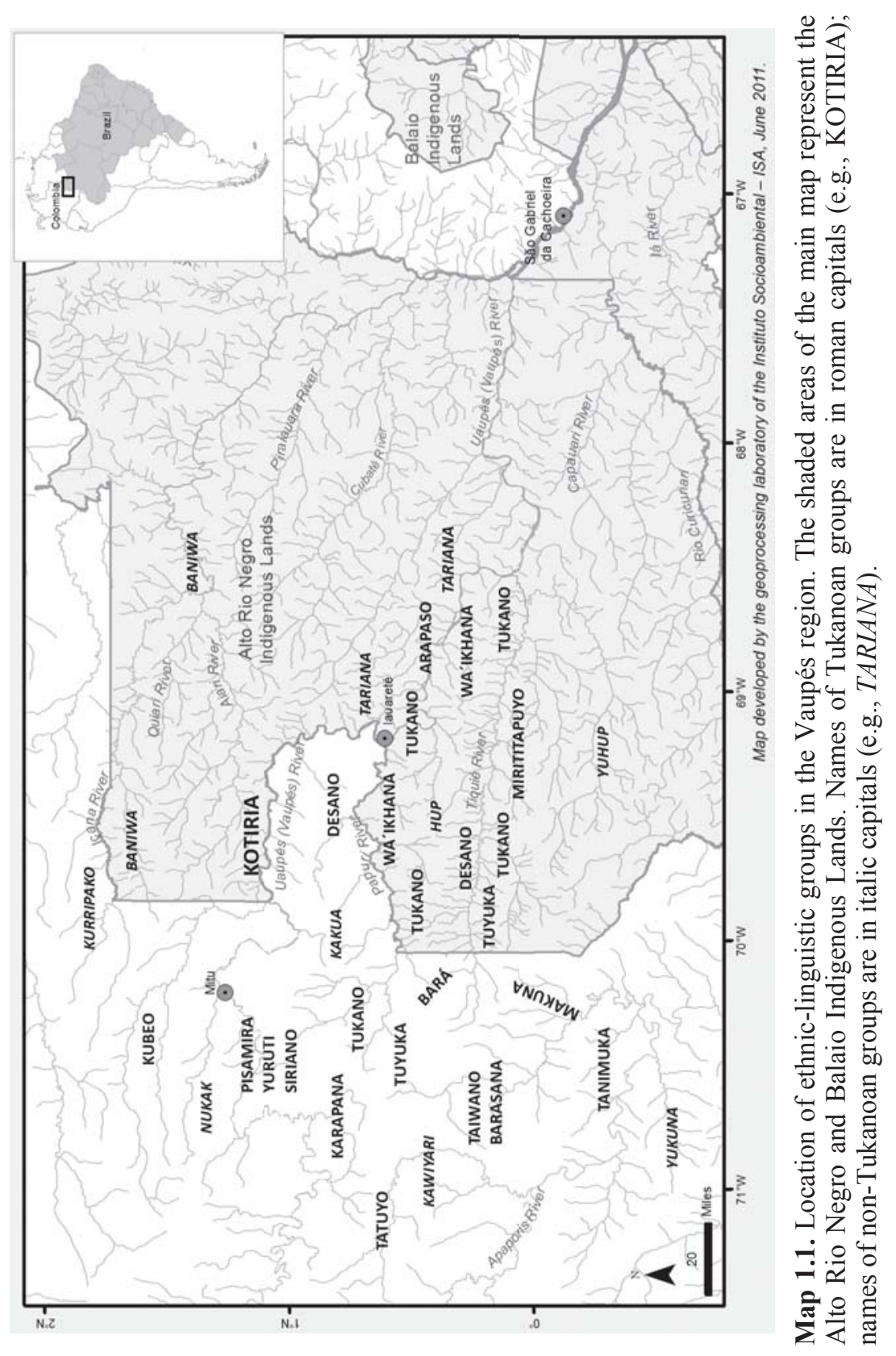


where it forms the border between Brazil and Colombia. Map 1.1 shows the region and locations of the major rivers - the Vaupés (Uaupés in Brazil) and its larger tributaries, including the Papurí and Tiquié; the Içana and its tributary, the Aiarí, to the north; and the Apaporis and its tributaries to the west - and the current spatial distribution of ethnic or language groups within it. Besides the Eastern Tukanoan groups, the map also shows the locations of Arawak groups (Baniwa, Kurripako, Tariana, Yukuna, Kawiyari) and groups in the Nadahup $^{14}$ (Hup, Yuhup, Nukak, Kakua) family.

The Kotiria live in twenty-one traditional communities along the Vaupés River. The Brazilian communities, beginning with the location furthest downstream, are Ilha de Japú (mu nuhko 'japú bird island'), ${ }^{15}$ Arara Cachoeira (maha phoa 'macaw rapids'), Ilha de Inambú (kha $n u h k o$ 'inambú bird island'), Poraque Ponta (sã'ama wahpa 'electric eel rapids'), Carurú Cachoeira (koama phoaye 'noisy stream rapids/ falls' or moa phoaye 'salt plant falls'), Jacaré (soma 'alligator creek'), Jutica (ñahpima 'sweet potato creek'), Taína (nihiphoto 'mouth of boy's creek'), and Taracuá (mene koana ñoaka 'black ant rapids'). All are located within the governmentally established and protected Alto Rio Negro Indigenous Lands (Área Indígena ARN).

The Colombian communities are Ibacaba (ñumu phoa), furthest downstream, Matapí (buhkakopa 'snare falls'), Taína Colombia, Igarapé Paca (sama nia phito 'mouth of white spotted agouti creek'), Macuco (phota phito 'mouth of thorn creek'), Ananás (sãne phoaka 'pineapple rapids'), Vila Fátima (boho phoa or wahte phoa 'tapioca rapids'), Inambú Ponta (kha phito 'mouth of hawk creek'), Tamanduá (mie phito 'mouth of anteater creek'), Santa Cruz (phoa wahpa 'hairy stone rapids'), Tabatinga (bohta phoa 'white clay rapids') and Taiaçú (yehse phoa 'pig rapids'). Kotiria communities in Brazil range in size from those with only a few houses and perhaps fifteen to twenty-five inhabitants to the largest village, Carurú Cachoeira, currently with some 140

\footnotetext{
${ }^{14}$ I utilize the language family denomination suggested by Epps (2008:9) rather than the more common "Makú," which is considered to be offensive. It should be noted that while Kakua and Nukak are generally identified as belonging to this language family, their genetic relationship to other Nadahup languages-Hup, Yuhup, Dâw, and Nadëb, the latter two spoken to the south of the area shown in the map-has yet to be completely substantiated (Epps 2008:3-9).

${ }_{15}$ Kotiria names and translations, where known, are given in parentheses. For an explanation of the transcription of Kotiria, see chapter 2, especially $\$ 2.10$. The names commonly used and that appear on maps are a mixture of Língua Geral (Nheengatú), Portuguese, or Spanish.
} 
inhabitants. ${ }^{16}$ The largest of the Colombian communities is Villa Fátima, with several hundred residents (primarily but not exclusively ethnic Kotiria); it is located upriver to the west in Colombia, close to the town of Mitú and within territory occupied primarily by the Kubeo.

According to two studies undertaken by the Instituto Socioambiental during the last decade, 140 Kotiria (approximately 19 percent of the total population in Brazil) reside in the mission town of Iauaretê (Andrello, Buchillet, and Azevedo 2002), and 101 Kotiria (14 percent) currently live in the city of São Gabriel da Cachoeira (Federação das Organizações Indígenas do Rio Negro and Instituto Socioambiental 2005:20). There are no statistics on the number of Kotiria residing in the town of Mitú, in Colombia.

Historical records analyzed by Wright (2005:80-81) confirm Kotiria occupation of this same territory in the 1740s, and the history of the region reconstructed through oral narratives and archeological evidence indicates a much older occupation pre-dating the Tariana migration to the Vaupés region approximately seven hundred years ago (Amorim1987; Neves 1998:158, 206; Wright 2005:13). We can see from the map that the geographic location of the Kotiria is somewhat removed from the core region occupied by other Eastern Tukanoan groups. This has kept them in close contact with two Arawak groups with whom they have formed long lasting "in-law" relations (see $§ 1.5$ below): the Tariana, whose territory on the Vaupés begins just downriver from the Kotiria (two of the three remaining Tariana-speaking communities are located there), and one of the Baniwa subgroups, who live on the Aiarí river but are easily reached via several relatively short overland trails (see Koch-Grünberg 1995, vol. 1:167-76; Neves 1988:116-17). The Kotirias' closest neighbors upriver on the Vaupés are the Eastern Tukanoan Kubeo, who have also had intense historical relations with the Baniwa (see Goldman 1963; Koch-Grünberg 1995, vol. 2:68; Gomez-Imbert 1996:446; Wright 2005:11). Interestingly, the Kubeo sib with whom the Kotiria maintain in-law relations, the Yurémava, is also the sib with the greatest Arawak linguistic influence; they are purported to be descendents of speakers of the Arawak language Inkacha who migrated to the Querarí river in Kubeo territory and assimilated into the local population. ${ }^{17}$

We can thus see that the Kotiria sociolinguistic context includes notable Arawak influence. The history of the relations between the

\footnotetext{
${ }^{16}$ The population of the village fluctuates somewhat because Carurú is the site of the Khumuno Wu't Kotiria Indigenous School and some families reside there only during the school year.

${ }^{17}$ According to Simón Valencia López, a Kubeo linguist and member of this sib (p.c. 2004). See also Valencia López (1994).
} 
Kotiria, the Kubeo, and the Arawak Baniwa and Tariana is reflected in physical evidence, in oral and cultural traditions of many different types (Koch-Grünberg 1995, vol. 2:63; Wright 2005:89; Amorim 1987), and in a number of diffused linguistic traits (discussed in Stenzel and Gomez-Imbert 2009).

Indeed, according to one origin myth, the name Kotiria was given to the group's original ancestor by the Kubeo. This ancestor existed in spirit form and lived in a hollow tree. Once, this spirit took on the form of a handsome man and went to a Kubeo ceremony, where he enchanted the women and lured them back to his tree. The next day, the Kubeo men followed their trail to the tree and decided to burn it, but each time the fire was lit, water descended from the tree to douse the flames. The Kubeo thus concluded that the beings inside must be Kotiria 'water people'. Eventually, though, the fire took, and the spirit of the Kotiria left the tree and traveled to the great Ipanoré rapids (some two hundred kilometers downriver on the Vaupés), from which all the Tukanoan peoples are believed to originate. The great spirit Ko 'amaku lived there, and he blew smoke on the spirit of the Kotiria, who then became human. After all the different groups had been created, there was a great celebration and dances were given to each group, but the Kotiria ancestor, Muktiro, claimed the most beautiful dances and traveled upriver to the great falls at what is now Carurú and stopped at the rock called Khumuno Wu'tt 'house of the shaman'. Muktiro claimed this rock and the surrounding area as home for his people. $^{18}$

In keeping with Vaupés social norms (described in $§ 1.5$ ), to this day the alliances the Kotiria have maintained with the Kubeo, Tariana, and Baniwa are reflected in marriage practices. Approximately 50 percent of Kotiria men are currently married to women from one of these three groups, ${ }^{19}$ and we can assume that all three languages historically figured in the repertoire of languages spoken by in-marrying wives in traditional Kotiria communities. Indeed, a small survey of self-evaluated language proficiency among a group of forty Kotiria men shows Baniwa and Kubeo to be among the languages most widely known, the other most commonly-spoken languages being Tukano, Desano, and Tuyuka (Stenzel 2005:20-21). It is not surprising that the Tariana lan-

18 This myth was recounted by Jesuíno Trindade and was transcribed and translated by his son José Galves Trindade in November 2003. The name of the Kotiria Indigenous School, Khumuno Wu' $t$, refers to this origin myth.

${ }_{19}$ Data on marriages in twelve communities was collected in September 2004 by the author and Lucia Alberta Andrade de Oliveira of the Instituto Socioambiental. Data on marriages of Kotiria men residing in Iauaretê are from Andrello, Buchillet, and Azevedo (2002). No information from the Kotiria communities upriver in Colombia is currently available. 
guage no longer figures in the Kotirias' linguistic repertoire, despite the large number of marriages between Kotiria men and Tariana women (over 25 percent); it simply reflects the fact that over the past century and a half, nearly all ethnic Tariana have shifted to use of Tukano.

\subsection{A brief history of contact}

Although they live in a region that is extremely remote and even today difficult to reach, the indigenous peoples who live along the Upper Rio Negro and its tributaries have had various types of contact with outsiders for nearly five hundred years. ${ }^{20}$ The first mention of the Vaupés (Uaupés) river is found in the records of the Philip von Hutten and Hernan Perez de Quesada expedition (1538-41), which followed the Orinoco river inland in search of El Dorado. The first reference to the river with "water black as ink" (the Rio Negro) is found in the 1542 records of the expedition headed by Francisco Orellana, traveling inland on the waterway now known as the Amazon. Neither of these records makes mention of the inhabitants of the region.

During the 1600s, occupation of the northern coastal areas of the continent by Europeans led to further exploration, and from the early part of the century, indigenous people from the upper Rio Negro region were captured by Carib groups invading from the north, who enslaved them and traded them to the Dutch. Throughout the 1700s, numerous Portuguese expeditions penetrated from the east, enslaving thousands of Indians and spreading diseases such as smallpox and measles, which all but wiped out entire populations.

The Jesuits arrived in the late 1700s and from their base in São Gabriel da Cachoeira established a mission at Ipanoré, midway between São Gabriel and Iauaretê, where nearly impassible rapids posed a natural impediment to further upriver exploration. Missionary activity expanded in the 1800 s, first by the Capuchins, and later by other Franciscan orders, alongside official programs for the resettlement of Indians from the Içana, Vaupés, and Xié rivers to Ipanoré and other upriver missions. The practice of resettlement continued into the twentieth century, despite the Indians' resistance to policies dictating that they should leave behind their traditional lifestyle and social organization, adopt new agricultural methods, provide labor and forest products for colonists, defend territories claimed by the crown, and generally be educated in the ways of the dominant white Europeans.

${ }^{20}$ This brief summary is based on the detailed accounts of Chernela (1983) and (1993) as well as Federação das Organizações Indígenas do Rio Negro and Instituto Socioambiental (2006). 
The Salesian presence in the Upper Rio Negro area dates to the second decade of the twentieth century. Between 1915 and 1945, they founded missions in São Gabriel da Cachoeira (on the Rio Negro), Taracuá and Iauaretê (both on the Vaupés), and Pari Cachoeira (on the Tiquié), strategic locations that became centers of religious, educational, and mercantile activities. They established primary schools (first to fourth grade) in smaller communities and three large boarding schools at the missions. The most promising students were sent to live at these schools from about the age of nine (fifth grade), and some went on to study at secondary or technical schools in São Gabriel. These schools still exist, though they stopped boarding students in the late 1980s. Besides their focus on education, the Salesian presence had profound effects on everyday life in Indian communities. Appointed "animators" mediated relations between the missionaries and local populations, while catechists performed weekly religious rituals in the communities and encouraged the Indians to abandon their traditional beliefs and practices, including the habit of dwelling in communal longhouses (Chernela 1993:40-41).

The first mention of the Kotiria people appears in the records of naturalist Alfred Wallace's 1852 expedition along the Uaupés. Of the ten communities he mentions, only half are presently inhabited, among them Carurú, famous for its enormous rapids, which he describes as

greater than any we had yet seen-rushing amongst huge rocks down a descent of perhaps fifteen or twenty feet. The only way of passing this, was to pull the canoe over the dry rock, which rose considerably above the level of the water, and was rather rugged, being interrupted in places by breaks or steps two or three feet high. [Wallace 1969: 240]

In 1904-5, the German ethnologist Theodor Koch-Grünberg traveled in the region and spent several weeks among the Kotiria. He published a Kotiria wordlist (Koch-Grünberg 1913-16), and his account of his travels contains detailed descriptions of settlements such as Matapí and Carurú, whose population he then estimated at two hundred; information on the history and occupation of Kotiria territory; accounts of the relations between the Kotiria, Baniwa, and Kubeo; as well as observations of exchange ceremonies, dances, and burial practices. He made some of the first observations of the numerous petroglyphs that are found throughout the region (Koch-Grünberg 1995, vol. 2:55-67). 


\subsection{Linguistic exogamy, multilingualism, and the Vaupés social system}

The Kotiria people participate in the well-known exogamic and multilingual Vaupés social system originally described by Sorensen (1967) and further documented in studies by linguists and anthropologists such as Chernela (1983, 1989, 1993), Jackson (1983), Gomez-Imbert (1991, 1996, 1999b), Aikhenvald (1999, 2002a), and Stenzel (2005). For the people who participate in this system, patrilineal descent and social identification with one's father's language group (whether or not this is accompanied by de facto language use, as in the case of the ethnic Tariana who have undergone a process of language shift to Tukano), form the foundation of social organization, establishing boundaries between groups and providing each individual with an unalterable identity that defines his or her relationships to all other individuals in the system.

The Vaupés social system is based on a classificatory distinction between agnates (members of one's own group, who identify equally with one's father's language and are understood to be one's "relatives") and affines (potential marriage partners, members of other linguistic-ethnic groups). Agnatic relations confer the status of classificatory sibling on all males and females of one's own generation; all males of one's father's generation are considered to be one's classificatory uncles, and so on, though the terms used to refer to kinship relations and the vocatives used in traditional address reflect complex distinctions of rank within more general categories. ${ }^{21}$ Moreover, each group traditionally identifies certain other groups as agnates. In other words, for each group, there are other groups classified as belonging to the same phratry. Thus, even though they are speakers of different languages, members of such phratric groups are considered to be too closely related in historical and mythological terms to be eligible marriage partners. According to Chernela (1993:27-48), the Kotiria traditionally consider four groups to be "brother groups" and therefore unmarriageable: the Wa'ikhana, Arapaso, Siriano, and Tuyuka.

Outside affinal groups, on the other hand, are those with which one's group maintains ongoing marital exchanges; these groups are collectively classified as "in-laws." Marriage between agnates is expressly prohibited; the prescribed norm is marriage outside of one's own group, the principle of linguistic exogamy. ${ }^{22}$ While this basic

\footnotetext{
${ }^{21}$ See, for example, Chernela's discussion of such terms in Kotiria (1993:60-71) and C. Hugh-Jones's discussion of Barasana (1979:287-90).

${ }^{22}$ There are, however, two Eastern Tukanoan groups, the Makuna and the Kubeo, who recognize exogamous units within the language or group. As a result, for members
} 
principal might lead us to conclude that one can essentially marry anybody (as long as the person does not have agnate status), in fact one's potential pool of matrimonial candidates is constrained by several other fundamental elements of the system.

First of all, individuals not only attune to the norm of proscribed marriage between agnates, but also strive to fulfill a prescribed ideal: marriage to a cross-cousin (the offspring of one's mother's brother or of one's father's sister) that also completes a bilateral de facto or symbolic exchange of sisters (Jackson 1983:126; see also the models in Stenzel 2005). Secondly, the general norm in Vaupés society is that of virilocal residence. In other words, upon marriage, a bride is expected to reside with her husband's group, quite often in her husband's natal community. This is, even today, a very strong tendency, as evidenced in a recent study of marriages in the Vaupés region (Azevedo 2005). ${ }^{23}$

Virilocal residence itself reflects and reinforces another grounding tenet of the system: the fundamental relationship between each language group and an established geographic territory. Indeed, geographic location is an essential factor in determining which language groups maintain long-term contact through marriage exchanges. Studies such as those of Goldman (1963), C. Hugh-Jones (1979), Jackson (1983), Gomez-Imbert (1996), Cabalzar (2000), and Azevedo (2005) demonstrate that the "in-law" groups for any given community tend to be those that are geographically more accessible. The creation and maintenance of affinal relations with neighboring groups not only facilitates practical matters such as courtship visits by unmarried men to the communities of potential brides and exchanges of goods with, and travel after marriage to, in-law communities, but is also an important means of strengthening regional social, political, economic, and (in the past) defensive alliances. ${ }^{2}$

Vaupés social organization, based as it is on patrilineal language group affiliation, exogamic marriage norms (constrained by geographic location and the prescribed ideals of cross-cousin unions and sister exchange), and the practice of virilocality, has several important linguistic consequences. The first is multilingualism at intersecting regional, community, familial and individual levels. As is seen in the map above, the region is home to speakers of some twenty-five in-

of these groups, it is possible to marry a speaker of the same language. For additional information, see Chernela (1989) and Gomez-Imbert (1999b).

${ }^{23}$ The study is based on data from the Censo Indígena Autônoma do Rio Negro, which was carried out among 16,897 people in 314 indigenous communities as well as the city of São Gabriel da Cachoeira. The data are analyzed in relation to five geographic subregions: Iauaretê, Tiquié/Uaupés, Içana, Upper Rio Negro, and Lower Rio Negro.

${ }^{24}$ For a summary of the literature addressing this issue see Azevedo (2005:39-40). 
digenous languages from three different language families. Among those groups who participate in the marriage system based on linguistic exogamy (basically the Eastern Tukanoan and Arawak groups), each local community is comprised of a group of men sharing the same ethnic identity and language and their multiethnic wives, who generally come from a circumscribed set of in-law groups. The children of the community identify ethnically and linguistically with their fathers, but are additionally exposed to and learn, to a greater or lesser extent, their mothers' languages and the languages spoken by the other in-marrying wives. Thus, each individual is raised in a bilingual household within a multilingual community and will acquire linguistic knowledge that reflects the local language repertoire. Additionally, all individuals are expected to master the national language (Portuguese or Spanish), as well as any locally employed lingua franca, such as Tukano, in the Vaupés subregion.

The second consequence of the Vaupés system is, of course, intense, ongoing linguistic contact. One of the general results of this long-term contact has been the widespread diffusion of linguistic features such as tone, nasalization, use of serialized verb roots, switchreference marking, and evidential systems, leading researchers such as Dixon and Aikhenvald (1998:241) to describe the Vaupés as a distinct linguistic area (see also Epps 2005, and for a more detailed overview of Nadahup involvement, Epps 2007). Aikhenvald (2002a) further argues that the Vaupés linguistic area is rather unique in that there has been no historical dominance of any one group over the others; basically, the languages in contact share equal status, a situation that creates a type of convergence characterized by indirect, multilateral diffusion. ${ }^{25}$ In contrast to many contact situations, there is very little borrowing of lexical forms, a restriction that helps preserve each language as separate. This is why evidence of convergence must be sought in grammatical structures rather than in the lexicons of specific languages (Aikhenvald 2002a:266-67).

Gomez-Imbert also contributes some important insights into the nature and results of linguistic contact among the groups of the Vaupés system. She characterizes the system as composed of the opposing yet

${ }^{25}$ However, it should be noted that historically, the egalitarian social conditions that permit such multilateral diffusion probably only existed internally, among the Eastern Tukanoan groups, and perhaps between intermarrying Eastern Tukanoan and Arawak groups (see Stenzel and Gomez-Imbert 2009). No such conditions have ever existed between Eastern Tukanoan and Nadahup groups and research has shown fairly unidirectional influence of Tukanoan languages on Nadahup languages (see Epps 2005, 2007). Moreover, over at least the past one hundred to 150 years, there has been massive Tukanoan influence on Tariana (Arawak), extensively documented by Aikhenvald (e.g., 2002a, 2003b). 
complementary processes of convergence and divergence, fusion (in which features of diverse languages become more alike), and fission (in which distinctions between languages become more accentuated). The inevitable interference of a child's mother's language on the acquisition and use of the father's language is an impetus for convergence, inducing fusion in the long term. On the other hand, speakers make "conscious and explicit efforts" to emphasize the differences between languages so that the uniqueness of each group's identity (language) can be preserved. Such marked differentiation stimulates divergence, ensuring that groups remain distinct over long periods of time (Gomez-Imbert 1991:547).

\subsection{The specter of language loss and the development of language maintenance programs}

The sociolinguistic characteristics of the Vaupés system described above are still generally attested among the Kotiria who reside in traditional communities (for a more detailed overview, see Stenzel 2005). The majority of the Kotiria continue to live within their established territory and generally maintain longstanding marriage alliances with their closest geographic neighbors. The principles of virilocal residence and the norms regarding language use within Kotiria communities are also in force: in-marrying wives are still expected to learn their husbands' language and to use it in public settings, and children acquire and use Kotiria as their language of identity. Thus, in Kotiria community settings, the language remains quite robust and patterns of individual and community multilingualism of the type described earlier can still be found.

However, there is an observable decline in use of the language among the Kotiria who move away from traditional communities and come to reside in communities such as Iauaretê and São Gabriel da Cachoeira. Migration has been on the rise over the past several decades due to a number of different factors, the most important being the need for families to accompany children completing their secondary school education. Others migrate in search of employment opportunities, because of health care concerns, or due to irresolvable conflicts in their communities. Whatever the motives behind migration, Kotiria speakers outside of their traditional communities inevitably encounter new linguistic environments that require them to adopt languages other than Kotiria for daily use and make maintenance of their own native language extremely difficult. Language shift for some indigenous migrants occurs in stages, and may include an initial shift to Tukano. Parallel or subsequent to this shift to the local indigenous lingua franca, 
displaced Kotiria use the national language - necessary for school, access to public resources, and military service - more and more as the language of their daily lives.

It is nearly inevitable that Kotiria children raised in urban centers such as São Gabriel will become monolingual in Portuguese within two generations. I have observed that children of adults who were raised in the traditional communities have a good passive comprehension of the Kotiria still spoken by the older members of their family, but they usually do not speak it themselves. Current socioeconomic conditions that promote migration and consequent language shift thus exacerbate the threat of endangerment and make linguistic maintenance efforts all the more urgent. Luckily, such efforts are already underway.

The Kotiria display an acute awareness of the importance of language preservation and an eagerness to invest in projects to maintain and strengthen use of their language. They have observed the process of language loss among other groups in the region and among the migrant members of their own language community, and are very aware that although the language is still robust in traditional contexts, the situation, even there, could change quickly and drastically. Thus, they are working to develop strategies to reverse language shift tendencies and are steadfastly investing in projects that will protect and fortify their culture and language.

Over the past two decades, and particularly since the late 1990s, the Kotiria and other indigenous groups in the Upper Rio Negro region have been increasingly involved in political organization, founding local councils and sending representatives to meetings and workshops on everything from health care to fish farming, from the revitalization of traditional arts to the development of literacy materials for local schools. They have established local representative associations, entered the regionally powerful Federation of Indigenous Organizations of the Rio Negro (Federação das Organizações Indígenas do Rio Negro [FOIRN]), and established alliances with non-governmental organizations such as the Instituto Socioambiental (ISA).

Among a variety of projects, including research on and documentation of cultural practices, demographic and geographic mapping, studies of environmental issues, and pilot projects on sustainable food production, ISA has worked with state and municipal education authorities to promote a number of programs related to indigenous education. From 1997 to 2007, ISA's Rio Negro Indigenous Education Project invested in efforts such as the Magistério Indígena, a training program for indigenous primary school teachers, guidance and funding for the publishing of didactic materials in indigenous languages, and support for the founding and development of autonomous indigenous schools 
in the region (first with the Baniwa and the Tuyuka in 2000, and later with the Kotiria in 2002, the Tukano in 2003, and the Tariana in 2005).

Indeed, the opportunity to consolidate my study of the language with more extensive community work came about in 2001, when a group of teachers and community leaders who were completing the training course for indigenous teachers decided it was time to form a Kotiria school based on the newly developing national ideals for indigenous education - essentially, that it be bilingual, self-determined, and culturally appropriate (see Stenzel 2006). To aid the process, they requested outside organizational and pedagogical assistance from ISA and asked if I could help with issues such as orthography and materials development. The school was officially founded in 2002 during my first linguistic workshop with the community.

In the ensuing years, we have worked together (and in conjunction with education specialists and anthropologists) not only to analyze the language, establish a writing system, and create literacy and other pedagogic materials, but also to document Kotiria traditions, history, verbal arts, knowledge of plants, animals, horticulture, astronomy, etc. Indeed, as the school has developed and expanded, so too has the language community's awareness of the need for much more extensive linguistic and cultural documentation, so much so that activities related to the full-fledged linguistic documentation project for Kotiria and Wa'ikhana (funded by the Hans Rausing Endangered Languages Project at the School of Oriental and African Studies, University of London, 2007-10) were incorporated into the curriculum for the newly founded (2007) Kotiria secondary school. A team of four students and their teacher coordinator were trained in basic documentary methodology, use of audio and video recording equipment, and basic annotation of the data. Among the products resulting from the documentation project is an archive of over sixty audio and video recordings of natural language use by speakers of different ages and from different villages. The recordings exemplify a number of different speech genres, from traditional narratives to casual conversation, from personal interviews to public speeches; they also a register examples of many different cultural situations, activities and traditional knowledge. Materials collected through the project have also been integrated into teaching materials, books, a practical grammar, and a multimedia dictionary for use in the school.

It has been a privilege to work with people such as the Kotiria, who, despite many past and present hardships, are so thoroughly invested in and optimistic about the future of their language and culture, as these words from the introduction to Wa'ikina Khiti 'Animal Stories' (text 
8 in appendix 1), the first primer written by the Kotiria, eloquently demonstrate:

A'rithu hira wa'ikina khiti yaya'urithu. Sã pho'na bu'eti hira. Ã yoana, sã kotiria ne bosi sã yahoare durukuare. A'ripa mahkaina, ba'aro mahkaina, hipitina. Wa'maropure, ñarana yare, bu'ena ñaro yu'dta thu'othui sã. Mipure sã yakotiria yare bu'ena phiro wahcheha. Yoaripa sã thu'oturi ba'aro a'rire süha. Ã yoana, a'ri thure hoaha sã kotiria. Setembro 2002 khu'ma hichu, yoarithu hira. Wa'ikina khiti kotiria ya me're.

'This is our own Kotiria animal storybook. It is our animal storybook, for our children to study. This way, we Kotiria won't forget how to write and speak our language. For those here now, and for those who come later, for everybody. When we were young, it was really hard for us to understand school in the white people's language. Now we're very happy to have our own Kotiria learning (writing system or school). What we've been thinking about for a long time has arrived That's why we Kotiria are writing this book. It's September of the year 2002, and we're making this book. Animal stories in our own Kotiria language.' 